\title{
Assessing Sediments from Upper Mississippi River Navigational Pools Using a Benthic Invertebrate Community Evaluation and the Sediment Quality Triad Approach
}

\author{
T. J. Canfield,* E. L. Brunson, F. J. Dwyer, C. G. Ingersoll, N. E. Kemble \\ Environmental and Contaminants Research Center, Biological Resources Division, U.S. Geological Survey, \\ 4200 New Haven Road, Columbia, Missouri 65201, USA
}

Received: 6 July 1997/Accepted: 11 February 1998

\begin{abstract}
Benthic invertebrate samples were collected from 23 pools in the Upper Mississippi River (UMR) and from one station in the Saint Croix River (SCR) as part of a study to assess the effects of the extensive flooding of 1993 on sediment contamination in the UMR system. Sediment contaminants of concern included both organic and inorganic compounds. Oligochaetes and chironomids constituted over $80 \%$ of the total abundance in samples from 14 of 23 pools in the UMR and SCR samples. Fingernail clams comprised a large portion of the community in three of 23 UMR pools and exceeded abundances of $1,000 / \mathrm{m}^{2}$ in five of 23 pools. Total abundance ranged from $250 / \mathrm{m}^{2}$ in samples from pool 1 to $22,389 / \mathrm{m}^{2}$ in samples from pool 19. Abundance values are comparable with levels previously reported in the literature for the UMR. Overall frequency of chironomid mouthpart deformities was 3\% (range $0-13 \%$ ), which is comparable to reported incidence of deformities in uncontaminated sediments previously evaluated. Sediment contamination was generally low in the UMR pools and the SCR site. Correlations between benthic measures and sediment chemistry and other abiotic parameters exhibited few significant or strong correlations. The sediment quality triad (Triad) approach was used to evaluate data from laboratory toxicity tests, sediment chemistry, and benthic community analyses; it showed that $88 \%$ of the samples were not scored as impacted based on sediment toxicity, chemistry, and benthic measures. Benthic invertebrate distributions and community structure within the UMR in the samples evaluated in the present study were most likely controlled by factors independent of contaminant concentrations in the sediments.
\end{abstract}

The Mississippi River is the central catchment for a majority of the water runoff between the west side of the Appalachian

\footnotetext{
* Present address: Robert S. Kerr Environmental Research Laboratory, United States Environmental Protection Agency, 919 Kerr Research Drive, Ada, Oklahoma 74820, USA

Correspondence to: T. J. Canfield
}

mountain range and the east side of the Rocky mountain range. This makes the Mississippi River system the largest in the United States, the third largest drainage worldwide, and the seventh largest average discharge worldwide (Van der Leeden et al. 1990). The river receives inputs from municipal, agricultural, and industrial sources. Previous studies have examined the concentrations of organic and inorganic contaminants in the sediments from select pools in the Upper Mississippi River (Wiebe 1927; Bailey and Rada 1984; Wiener et al. 1984; Rada et al. 1990). Recently, some studies have reported a decline in the levels of contaminants in the sediments of the Upper Mississippi River (UMR) (Rada et al. 1990).

The UMR, that part of the river north of the confluence with the Ohio River at Cairo, Illinois, is divided into a series of large runs and pools by 26 locks and dams constructed for navigational purposes (Rada et al. 1990). This lock-and-dam system, which runs from Minneapolis, Minnesota to St. Louis, Missouri, provides areas for deposition of large quantities of fine-grained sediments during normal and low flows (Nielson $e t$ al. 1984). Contaminants are often associated with fine-grained sediments and settle along with these sediments (Forstner and Wittmann 1980; Hassett et al. 1980). Sediments often serve as a sink for an array of organic and inorganic contaminants when the water-to-sediment gradient is high, and these sediments can act as a source of contamination when the water-to-sediment gradient is low (Shimp et al. 1971; Oschwald 1972; Medine and McCutcheon 1989).

Benthic macroinvertebrates inhabiting the sediments are presumably exposed continuously to any contaminants contained in the sediments. Benthic macroinvertebrate abundance, community structure, and ecological function have long been used to characterize water quality in freshwater ecosystems (Davis and Lathrop 1992). Numerous studies have documented changes in benthic invertebrate community structure associated with the impacts of contaminants (Cook and Johnson 1974; Rosenberg and Wiens 1976; Hilsenhoff 1982, 1987; Waterhouse and Farrell 1985; Clements et al. 1992). Most studies in lotic environments have examined the responses of benthic macroinvertebrate communities in riffle areas due to ease of collection and observed higher taxa richness. However, only a 
limited number of assessments have been conducted in depositional soft-sediments (Canfield et al. 1996).

The spatial and temporal distribution of resident organisms may reflect the degree to which chemicals in the sediments are bioavailable and toxic. Field surveys of invertebrates can provide an important component of biological assessments of toxicity associated with contaminated sediments for several reasons: (1) macroinvertebrates are abundant, relatively sedentary, easy to collect, and ubiquitous across a broad array of sediment types; (2) many indigenous benthic organisms complete all or most of their life cycles in the aquatic environment and may serve as continuous monitors of sediment quality; and (3) results of an assessment of indigenous populations may be useful for quantifying resource damage (Cook 1976; Pratt and Coler 1976; Davis and Lathrop 1992).

The United States Geological Survey (USGS) has been monitoring the UMR since 1987 to document the fate, transport, and distribution of contaminated sediments (Moody and Meade 1995). Concern with regard to the fate of contaminated sediments in the UMR arose after the flood of 1993, because of the possible for reexposure of deeply buried, potentially highly contaminated sediments. Furthermore, the flood inundated numerous riparian areas known to contain both diffuse and concentrated (i.e. fuel tanks, warehouses) sources of contaminants. This study was designed to evaluate the current status of sediments in the UMR and is one chapter in a scrics designed to assess the extent of sediment contamination in the navigational pools of the river. The overall study consisted of the following components: (1) monitoring concentrations of contaminants in the Mississippi River sediments (Moody 1996); (2) toxicity testing with whole sediments collected from the river (Kemble et al. 1998); (3) bioaccumulation tests with whole sediments collected from the river (Brunson et al. 1998); and (4) analysis of benthic invertebrate community structure. The objective of this portion of the study was threefold: (1) describe distributions and abundances of benthic invertebrates in soft sediments from selected locations in pools of the UMR; (2) evaluate impacts of contaminants associated with these sediments using measures of benthic invertebrate community structure; and (3) evaluate the concordance of benthic invertebrate assessments to sediment toxicity and sediment chemistry using the sediment quality triad approach.

\section{Materials and Methods}

\section{Sampling Locations}

Stations were selected for assessment of sediment toxicity, sediment chemistry, and benthic macroinvertebrate communities based on historical chemistry data (Moody 1996) and the availability of soft sediments (Kemble et al. 1998). UMR pools were sampled from June 11 to July 5 , 1994. Stations were located in 23 of 26 pools in the UMR from pool 1 near Hastings, Minnesota to pool 26 near St. Louis, Missouri (Figure 1). A complete description of the sampling locations in each pool is described in Kemble et al. (1998) and bioaccumulation data is contained in Brunson et al. (1998).

\section{Sediment Collection, Handling, and Storage}

Locations of stations for field sampling were determined with a Global Positioning System. A stainless stecl standard Ponar grab $(23 \times 23 \mathrm{~cm}$,
$529 \mathrm{~cm}^{2}$ area) was used to collect bulk sediments from about the upper 6 to $10 \mathrm{~cm}$ of the sediment for chemistry analyses, laboratory toxicity assessments, and benthic invertebrate assessments at one station per pool (Kemble et al. 1998). Each sample was a composite of 8-20 grab samples for a volume of 35-80 L of sediment/station (identified as $\mathrm{C}$ samples in Kemble et al. 1998). Sediments were placed in a $120-\mathrm{L}$ high-density polyethylene drum and mixed at low speed with a hand-held power drill and a stainless steel auger to allow complete mixing of sediment while leaving the animals undamaged. A $2.5-\mathrm{L}$ subsample of sediment for evaluations of benthos was obtained from the composite $\boldsymbol{C}$ sample hefore subsamples were obtained for chemistry and laboratory analyses (Kemble et al. 1998). To isolate the benthos, these 2.5-L subsamples were sieved through an ASTM No. 30 $(533 \mu \mathrm{m})$ and an ASIM No. $60(250 \mu \mathrm{m})$ bucket connected in series using screened river water for rinsing. Material containing benthos retained by the sieves was combined and transferred into 1-L highdensity polyethylene jars, preserved with $10 \%$ buffered formalin, and transported to the laboratory. Subsamples for use in toxicity and bioaccumulation testing $(10 \mathrm{~L})$, for chemical characterization $(250 \mathrm{ml}$ for metals, $250 \mathrm{ml}$ for organics), and for physical characterization (250 $\mathrm{ml}$ ) were taken and stored in high-density polyethylene containers or amber glass I-CHEM bottles (chemical characterizations only). All samples were stored at $4^{\circ} \mathrm{C}$ in the dark (Kemble et al. 1998). For a description of chemistry analyses and laboratory toxicity assessments conducted on these sediments, see Kemble et al. (1998).

\section{Taxonomic Identification}

The preserved samples of benthos were placed in a sieve $(250 \mu \mathrm{m})$ and rinsed thoroughly with tap water in the laboratory to remove formalin and excess silt or mud before sorting. The samples were drained of excess water, returned to the original jars, filled with $95 \%$ ethanol and allowed to soak for at least $24 \mathrm{~h}$ to facilitate extraction of volatile compounds. Aliquots of the sample were sequentially removed from the jar to sort benthic invertebrates until the entire sample had been sorted.

A binocular dissecting microscope ( $4 \times$ to $12 \times$ power) was used to sort and pick invertebrates from the entire sample. Invertebrates were initially sorted and enumerated into the following orders or families: Oligochaeta, Chironomidae, Bivalvia, Gastropoda, Ephemeroptera, Odonata, Plecoptera, Hemiptera, Megaloptera, Trichoptera, Coleoptera, Diptera, Hirudinea, and Amphipoda. Taxa were identified to the lowest practical level using appropriate taxonomic keys (Wiederholm 1983; Merritt and Cummins 1984; Pennak 1989; Thorp and Covich 1991). The following benthic macroinvertebrate metrics were calculated: macroinvertebrate abundance (number $/ \mathrm{m}^{2}$ ), species composition, and taxa richness (US EPA 1997). All taxa were either identified or verified by personnel at the Aquatic Resources Center in Franklin, TN.

Chironomid larvae (midge) were examined for deformities in mouthpart structures. These deformities, which included various types of asymmetry, missing teeth, extra teeth, fusion among various teeth, and labial separation, have been described by several investigators (Saether 1970; Hamilton and Saether 1971; Hare and Carter 1976; Warwick et al. 1987; Warwick 1989). Individual midges were mounted on slides and their mouthparts were examined for deformities in the mentum and ligula (Tanypodinae only). Occurrence of deformities was expressed as a proportion of the total number of midges at each station.

\section{Physical and Chemical Characterizations of Sediment}

Sediment physical characteristics included the following: (1) sediment particle size, (2) total organic carbon, (3) inorganic carbon, and (4) pereent water. Sediment chemical parameters included the following: 


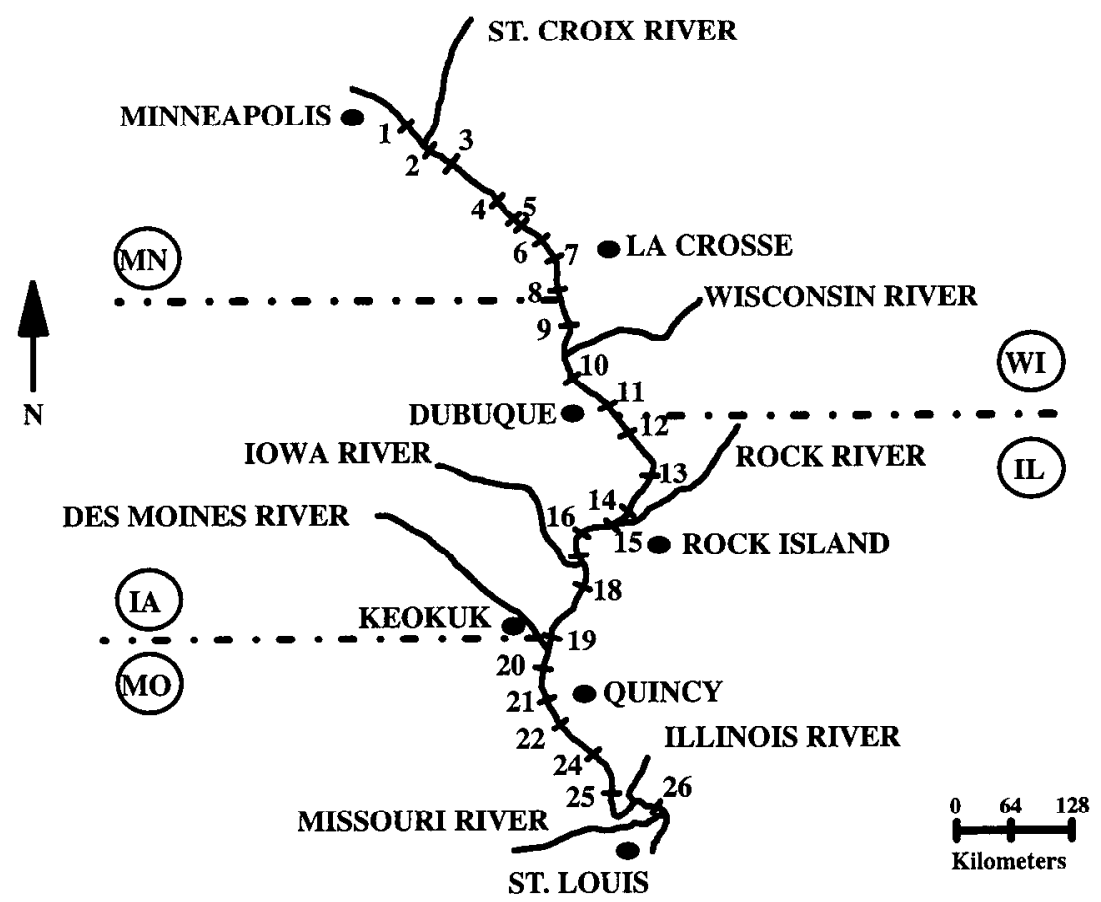

Fig. 1. Map of the Upper Mississippi River Pools from Minneapolis, Minnesota to St. Louis, Missouri
(1) chlorinated pesticides, (2) polychlorinated biphenyls (PCBs), (3) select aliphatic and polynuclear aromatic hydrocarbons (PAHs), (4) simultaneously extracted metals (SEMs), (5) acid volatile sulfide (AVS), and (6) total metals. See Kemble et al. (1998) for additional information on chemical and physical characteristics of the sediments.

\section{Statistical Analyses}

Statistical analysis was performed with the Statistical Analysis System (SAS 1994). Comparisons between benthic invertebrate abundance and physical and chemical data were made with a Spearman Rank correlation and multivariate regression. If not reported, statements of statistical significance indicate $\mathrm{p} \leq \mathbf{0 . 0 5}$.

\section{Sediment Quality Triad Assessments}

The sediment quality triad (Triad) approach was used as an effectsbased approach to integrate data from chemical and physical analyses (e.g., PAHs, metals, grain size), laboratory sediment toxicity tests (e.g., Hyalella azteca survival and growth), and metrics of benthic community structure and structural abnormalities (e.g., index of biotic integrity, taxa richness, midge mouthpart deformities) to evaluate the level of concordance between these three measures and the degree of contaminant-induced degradation in aquatic communities in softsediment depositional areas (Chapman et al. 1992). Toxicity, benthos, and chemistry data were scored using procedures developed by Kreis (1988) and data were plotted using procedures described by Canfield $e t$ al. $(1994,1996)$. Values for each individual variable for all samples were scaled proportionally between 1 and 100 (e.g., 1 is indicative of the lowest concentration or least impacted and 100 is the greatest concentration or most impacted). Scaling data retains proportional differences between measurements and results in an identical range for all variables. Typically, more than one variable is determined for a particular Triad component (e.g., H. azteca survival and growth). In these instances Kreis (1988) recommends: (1) scaling each individual variable among samples, (2) summing the scaled values for each variable, and then (3) rescaling the sums for all samples. This results in scaled scores (e.g., toxicity, benthos, or chemistry) between 1 and 100 for each Triad component, which can be compared graphically or in tabular form.

The high and low values used to establish scores for each of the sets of information for benthos, chemistry, and laboratory toxicity were previously reported in Canfield et al. (1996). To evaluate the extent of contamination of the UMR in the context of other areas with contaminant concerns in North America, we used data from three Great Lakes Areas of Concern (Canfield et al. 1996) and data from a study of the upper Clark Fork River, including Milltown Reservoir, in Montana (Canfield et al. 1994). Inclusion of these data sets provided a larger number of stations with a broad range in levels of contamination that could be used in the analyses of the relative responses of benthic communities in select sampling locations in the UMR and evaluate the relative contamination of sediments in the UMR sediments when compared to other areas. Six benthic invertcbrate indices were used in the evaluation of the extent of sediment contamination in the UMR system: (1) total taxa richness, (2) chironomid genera richness, (3) chironomid mouthpart deformities, (4) chironomid biotic index, (5) chironomid/oligochaete ratio, and (6) oligochaete biotic index. A biotic index is used to evaluate habitat quality (water or sediment) based on measures of the relative abundance of various taxa present at a site and the associated tolerance value of these taxa combined to produce a numerical score (Chutter 1972; Hilsenhoff 1982, 1987). The Hilsenhoff index of biotic integrity (Biotic Index) was used to calculate the biotic indices for both the midges and oligochaetes. Species sensitivity within genera were obtained primarily from those assigned by Hilsenhoff $(1982,1987)$ and secondarily by Lenat (1993).

To evaluate the chemistry portion of the Triad, we used effect-range median (ERM) concentrations calculated by Ingersoll et al. (1996). An ERM is defined as the concentration of a chemical in sediment above which effects are frequently or always observed (Long et al. 1995). We used seven ERM values that correctly classify laboratory toxicity $>$ $70 \%$ of the time in H. azteca 28-day tests (Ingersoll et al. 1996). These seven ERMs would more closely identify cause and effect toxicity rather than correlative toxicity (Canfield et al. 1996). These ERMs included: cadmium, nickel, lead, zinc, chrysene, benzo(a)pyrene, and benzo(g,h,i)perylene. 
To evaluate the laboratory toxicity portion of the Triad we used amphipod ( $\mathrm{H}$. azteca) 28-day growth and survival to score laboratory toxicity (Kemble et al. 1998). Amphipods are sensitive to contaminated sediments and frequently exhibit reduced survival and growth following exposures to contaminated sediments (Burton et al. 1996; Ingersoll et al. 1996). Each sample was designated as toxic when either survival or growth of $H$. azteca was significantly reduced relative to the control or reference sediment (Kemble et al. 1994, 1998; Ingersoll et al. 1996; US EPA 1993, 1994). Associations between benthic indices or laboratory toxicity tests and sediment chemistry were evaluated by plotting the scores of either the benthic indices or laboratory toxicity data against the sum of the ERM quotient (SERM-Q: ERM-Q = concentration of a chemical in sediment sample/ERM for that chemical) for all seven clemicals in a sample. This approach is similar to a toxic-unit approach.

Well-defined guidelines have not been developed for distinguishing impacts of contaminant effects on benthos found in soft sediments in either lakes, streams, or rivers. Canfield et al. (1996) incorporated data plots (partitioned by using quadrants defined by "no effect concentration data") and frequency analysis to examine the distribution of the data points to identify relations between sediment chemistry, laboratory toxicity, and benthic invertebrate distributions. This quadrantfrequency analysis (essentially a frequency analysis to identify correct classification and Type I and Type II error) was conducted in order to evaluate which benthic indices were most sensitive to elevated contaminant concentrations. In this analysis, scores for benthic indices were plotted against scores for chemical contamination in sediments. Quadrants were then defined, which identified one of four possible conditions: (1) low chemical concentration and benthos not adversely impacted, (2) elevated chemical concentration and benthos adversely impacted, (3) low chemical concentration and benthos adversely impacted (Type II error, false negative), and (4) elevated chemical concentration and benthos not adversely impacted (Type I error, false positive). Various combinations of benthic indices were evaluated by adding the individual scores and rescoring. These analyses were conducted for all possible combinations of the six scored benthic indices listed above.

Sediment toxicity studies were conducted on sediments from all of the UMR pools (except pools 3 and 17) (Kemble et al. 1998). The results of the tests on the UMR sediments were combined with data from 19 Great Lakes sediment samples (Ingersoll et al. 1996) and 13 Clark Fork River/Milltown Reservoir samples (Kemble et al. 1994) in order to evaluate the toxicity of the UMR sediments in the context of other samples previously evaluated. Based on previous plots of toxicity scores (Canfield et al. 1996), the vertical quadrant line, to the right of which no nontoxic samples were observed and where chemical contamination was considered "toxic," intersected the $\mathrm{X}$ axis at a sum of the ERM quotient of 39 (Figure 2). The horizontal quadrant line above which no "nontoxic" samples were observed intersected the Y axis at a laboratory toxicity score of 30 . This selection procedure for establishing quadrant lines may not be the most environmentally protective because some of the samples that had a sum of the ERM quotient score less than 39 were toxic to $H$. azteca in the laboratory studies (Kemble et al. 1994, 1998; Ingersoll et al. 1996).

Scores for each of the individual benthic indices and all combinations of combined benthic indices were plotted against the sum of the ERM quotient. The position of quadrant lines for benthic indices were determined in three steps: (1) plotting the data, (2) drawing the vertical quadrant line at 39 for the sum of the ERM quotient, and (3) by evaluating the distribution of the data and selecting a benthic score (horizontal quadrant line), which maximized the number of points in quadrants that would be considered "correctly classified" and minimized the number of samples with "Type I, false positive" and "Type II, false negative" error results.

Raw data for sediment and tissue analyses, as well as benthic invertebrate assessments are presented in US EPA (1997) and are also available on the Web at our home page (http://www.ecrc.cr.usgs.gov/ pubs/umr.html).

\section{Results and Discussion}

\section{Benthic Invertebrate Assessments}

Abundance: Benthic invertebrates from the UMR exhibited a wide range of abundance values. Benthic invertebrate abundance (number $/ \mathrm{m}^{2}$ ) in samples ranged from $250 / \mathrm{m}^{2}$ in sample $1 \mathrm{C}$ to a maximum of $22,389 / \mathrm{m}^{2}$ in sample $19 \mathrm{C}$ (Table 1 ). Total abundance values were less than $8,000 / \mathrm{m}^{2}$ in 21 of 24 samples with the remaining three samples having abundance values twoto threefold greater than any of the other samples. Oligochaetes were numerically dominant in 12 of 24 samples. Midges comprised the majority of the community in eight of 24 samples with the bivalves (two), mayflies (one), and nematodes (one) comprising the majority of the community in four of 24 samples (Table 1) (US EPA 1997).

Oligochaete abundance ranged from $63 / \mathrm{m}^{2}$ in sample $5 \mathrm{C}$ to $12,111 / \mathrm{m}^{2}$ in sample 19C (Table 1). There were order of magnitude differences in abundance values among the pools. In general, oligochaete abundance was lowest in samples from the upper pools (1 through 7) and higher in the lower pools (Table 1). We expected these differences to be explained by organic carbon and grain size, however, no significant correlations among these variables were observed with this data set (Table 2).

Chironomid abundance ranged from zero in samples from station $7 \mathrm{C}$ to $8,889 / \mathrm{m}^{2}$ in samples from station $15 \mathrm{C}$ (Table 1). Distribution of midges was fairly even across this range. These values for chironomid abundances were generally higher than those reported from contaminated sediments in Milltown Reservoir/Clark Fork River (Canfield et al. 1994) or the Great Lakes (Canfield et al. 1996).

Community Composition: Samples from the UMR had a moderately diverse benthic invertebrate community (Table 1). Overall taxa richness was greater in samples from the lower two-thirds of the river than in the upper eight pools. Oligochaetes accounted for $5-90 \%$ of the total abundance in all samples. Oligochaetes and midges together accounted for $8-100 \%$ of the total abundance in all samples, with the Bivalvia and Ephemeroptera accounting for most of the remainder of the benthic community.

The oligochaete community was comprised of two families, five genera, and nine species (US EPA 1997). Samples from $20 \mathrm{C}$ and $11 \mathrm{C}$ had the highest number of species, while samples from $1 \mathrm{C}, 4 \mathrm{C}$, and $5 \mathrm{C}$ each had only one species. Except for $10 \mathrm{C}$, the oligochaete community was made up entirely of the family Tubificidae. Limnodrilus spp., generally considered tolerant of organic and metal contamination (Kennedy 1965; Brinkhurst et al. 1972; Burt et al. 1991), was the most common genus occurring in samples from the UMR.

The midge community was comprised of four subfamilies (Chironomini, 'Tanipodinae, Tanytarsini, and Orthocladinae) and 18 genera (US EPA 1997). The sample from station 10C had the highest number of genera present (eight), while the sample from station 7C had no midge present. Chironomus spp. was the most abundant genus present in 17 of 24 samples, while Procladius spp. was the most abundant in 3 of the remaining samples. 


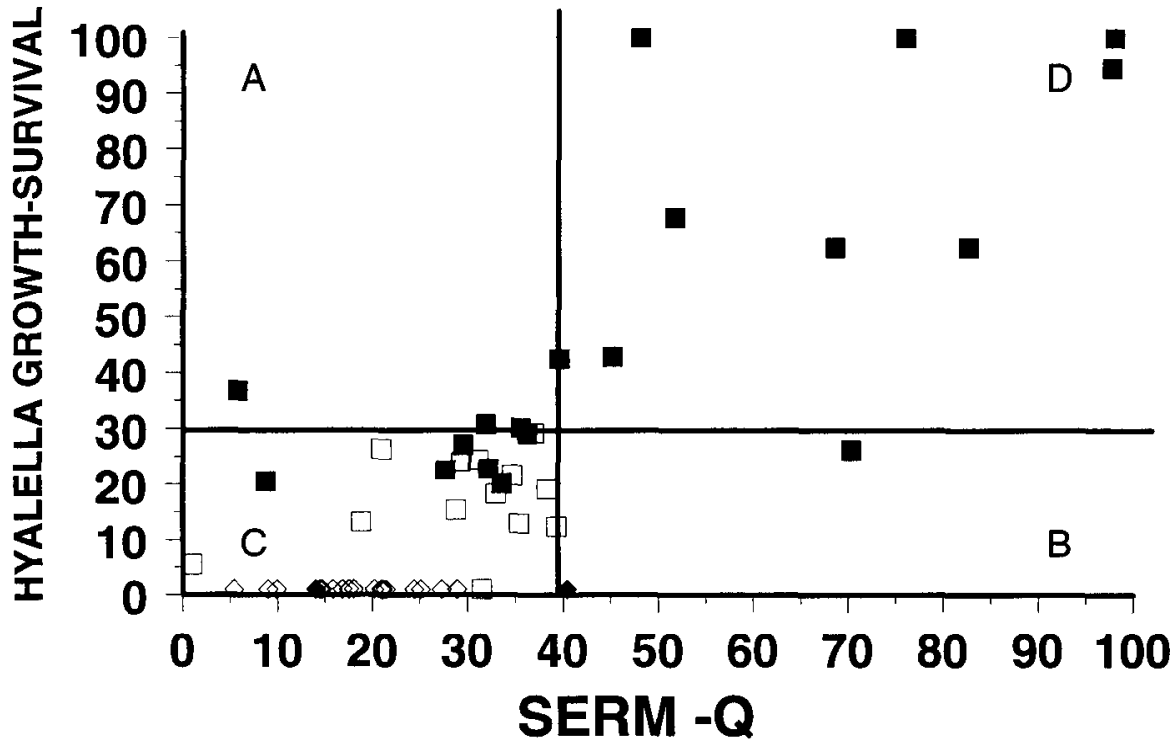

Fig. 2. Quadrant analysis with the Hyalella azteca toxicity score and the SERM-Q. Quadrants are labeled: A: false negative (Type II error; high toxicity, low chemistry), B: false positive (Type I error; low toxicity, high chemistry), $\mathrm{C}$ : nonimpacted (low toxicity, low chemistry), D: impacted (high toxicity, high chemistry). A dark square or diamond indicates toxic samples and an open square or triangle indicates nontoxic samples in Hyalella azteca toxicity tests. A square (either dark or open) indicates data from samples collected in the Great Lakes and Milltown Reservoir/Clark Fork River, Montana, and a diamond (either dark or open) indicates data from samples collected in the Upper Mississippi River

Table 1. Percent contribution of each taxa to the overall total abundance estimates ${ }^{\mathrm{a}}$

\begin{tabular}{|c|c|c|c|c|c|c|c|c|c|c|c|c|c|}
\hline \multirow[b]{2}{*}{ Sample } & \multicolumn{12}{|c|}{ Taxa } & \multirow[b]{2}{*}{ Total } \\
\hline & OL & $\mathrm{CH}$ & BIVL & EPHM & ODON & HEM & TRI & DPT & HR & AMP & NEMA & HDRNID & \\
\hline SCC & 32 & 63 & 2 & 0 & 0 & 0 & 0 & 0 & 0 & 0 & 2 & 0 & 2,733 \\
\hline $1 \mathrm{C}$ & 33 & 67 & 0 & 0 & 0 & 0 & 0 & 0 & 0 & 0 & 0 & 0 & 250 \\
\hline $2 \mathrm{C}$ & 43 & 36 & 0 & 20 & 0 & 0 & 0 & 0 & 0 & 0 & 0 & 0 & 2,933 \\
\hline $4 \mathrm{C}$ & 18 & 3 & 0 & 3 & 0 & 0 & 0 & 0 & 0 & 0 & 75 & 1 & 3,381 \\
\hline $5 \mathrm{C}$ & 11 & 33 & 22 & 22 & 0 & 0 & 11 & 0 & 0 & 0 & 0 & 0 & 563 \\
\hline $6 C$ & 53 & 26 & 3 & 5 & 0 & 2 & 0 & 7 & 0 & 2 & 2 & 0 & 1,611 \\
\hline $7 \mathrm{C}$ & 12 & 0 & 62 & 22 & 0 & 0 & 1 & 0 & 0 & 1 & 1 & 0 & 4,222 \\
\hline $8 \mathrm{C}$ & 43 & 35 & 0 & 18 & 1 & 0 & 0 & 2 & 0 & 0 & 0 & 0 & 4,000 \\
\hline $9 \mathrm{C}$ & 5 & 3 & 77 & 9 & 0 & 0 & 1 & 0 & 2 & 4 & 0 & 0 & 21,611 \\
\hline $10 \mathrm{C}$ & 46 & 51 & 2 & 0 & 0 & 0 & 0 & 0 & 0 & 0 & 0 & 0 & 4,071 \\
\hline $11 \mathrm{C}$ & 63 & 29 & 1 & 5 & 0 & 0 & 1 & 0 & 0 & 0 & 1 & 0 & 2,581 \\
\hline $12 \mathrm{C}$ & 7 & 30 & 19 & 35 & 0 & 1 & 0 & 2 & 1 & 1 & 4 & 0 & 7,611 \\
\hline $13 \mathrm{C}$ & 39 & 27 & 14 & 6 & 0 & 0 & 0 & 0 & 10 & 5 & 0 & 0 & 7,294 \\
\hline $14 \mathrm{C}$ & 75 & 20 & 2 & 0 & 0 & 0 & 0 & 2 & 0 & 0 & 0 & 0 & 5,500 \\
\hline $15 \mathrm{C}$ & 53 & 44 & 1 & 1 & 0 & 0 & 0 & 1 & 0 & 0 & 1 & 0 & 20,222 \\
\hline $16 \mathrm{C}$ & 46 & 53 & 0 & 0 & 1 & 0 & 0 & 0 & 0 & 0 & 0 & 0 & 3,909 \\
\hline $18 \mathrm{C}$ & 28 & 69 & 3 & 0 & 0 & 0 & 0 & 0 & 0 & 0 & 1 & 0 & 5,583 \\
\hline $19 \mathrm{C}$ & 54 & 25 & 6 & 15 & 0 & 0 & 0 & 0 & 0 & 0 & 0 & 0 & 22,389 \\
\hline $20 \mathrm{C}$ & 90 & 6 & 1 & 2 & 1 & 0 & 1 & 1 & 0 & 0 & 0 & 0 & 1,702 \\
\hline $21 \mathrm{C}$ & 16 & 60 & 0 & 18 & 3 & 0 & 0 & 3 & 0 & 0 & 0 & 0 & 2,429 \\
\hline $22 C$ & 67 & 30 & 2 & 0 & 0 & 0 & 2 & 0 & 0 & 0 & 0 & 0 & 3,389 \\
\hline $24 \mathrm{C}$ & 13 & 75 & 2 & 6 & 0 & 0 & 0 & 4 & 0 & 0 & 0 & 0 & 2,000 \\
\hline $25 \mathrm{C}$ & 78 & 16 & 3 & 3 & 0 & 0 & 0 & 0 & 0 & 0 & 0 & 0 & 4,808 \\
\hline $26 \mathrm{C}$ & 55 & 45 & 0 & 0 & 0 & 0 & 0 & 0 & 0 & 0 & 0 & 0 & 2,286 \\
\hline
\end{tabular}

a Values for total abundance (Total) are actual numbers of organisms estimated in each sample standardized by unit area $\left(\mathrm{m}^{2}\right)$

OL-Oligochaeta; $\mathrm{CH}-$ Chironomidae; BIVL-Bivalvia; EPHM-Ephemeroptera; ODON_Odonata; HEM-Hemiptera; TRI-Trichoptera; DPT_-Diptera; HR-Hirudinea; AMP-Amphipoda; NEMA-Nematoda; HDRNID-Hydrachnida

Sample numbers designate the pools in the Upper Mississippi River where the samples were taken. The sample number SCC corresponds to the sampling site in the Saint Croix River

The Bivalvia (clams) and aquatic insects (excluding midge) comprised a large part ( $>20 \%$ ) of the community collected in 11 of 24 samples (US EPA 1997). Bivalvia abundance ranged from zero in seven samples to $16,722 / \mathrm{m}^{2}$ in sample $9 \mathrm{C}$ (Ta- ble 1). The Bivalvia were present in 17 of 24 samples. Bivalvia abundance was greater than or equal to $1,000 / \mathrm{m}^{2}$ in five of 24 samples. Bivalvia abundance of $16,722 / \mathrm{m}^{2}$ in sample $9 \mathrm{C}$ is one to two orders of magnitude greater than all other samples 
Table 2. Spearman rank correlation for whole sediment measured naphthalene (NAPH), chrysene (CHRYS), benzo(a)pyrene (BAP), cadmium $(\mathrm{Cd})$, nickel $(\mathrm{Ni})$, lead $(\mathrm{Pb})$, zinc $(\mathrm{Zn})$, percent water $\left(\% \mathrm{H}_{2} \mathrm{O}\right)$, percent sand (\%SAND), percent silt (\%SILT), percent clay (\%CLAY), total organic carbon (TOC) with oligochaete abundance (OL), chironomid midge abundance (CH), bivalve abundance (BIVL), mayfly abundance (EPHM), total abundanec (Total), number of oligochaete taxa (OTAXA), number of chironomid midge taxa (MTAXA), oligochaete biotic index (OLBI), chironomid midge biotic index, ratio of oligochaetes to chironomid midge (MGOLRAT), chironomid midge mouthpart deformities (MGDFRM), chironomid midge genera richness (MGRICH), and total taxa richness (TXRICH) ${ }^{\mathrm{a}}$

\begin{tabular}{|c|c|c|c|c|c|c|c|c|c|c|c|c|}
\hline Metric & NAPH & CHRYS & BAP & $\mathrm{Cd}$ & $\mathrm{Ni}$ & $\mathrm{Pb}$ & $\mathrm{Zn}$ & $\% \mathrm{H}_{2} \mathrm{O}$ & $\%$ SAND & $\%$ SILT & \%CLAY & TOC \\
\hline $\mathrm{OL}$ & 0.21 & 0.15 & -0.09 & -0.23 & 0.07 & 0.11 & 0.13 & -0.07 & -0.32 & 0.17 & 0.29 & 0.09 \\
\hline $\mathrm{CH}$ & 0.04 & 0.03 & -0.01 & -0.06 & -0.08 & 0.24 & 0.32 & -0.17 & -0.39 & 0.07 & $0.48^{*}$ & 0.11 \\
\hline BIVL & 0.28 & -0.04 & -0.25 & 0.09 & 0.21 & 0.38 & 0.37 & -0.24 & -0.33 & -0.17 & $0.49^{*}$ & 0.19 \\
\hline EPHM & 0.34 & -0.21 & -0.01 & -0.10 & 0.16 & 0.0 & 0.04 & -0.22 & $-0.43^{*}$ & 0.09 & $0.47^{*}$ & 0.03 \\
\hline Total & 0.39 & 0.08 & 0.0 & 0.10 & 0.26 & 0.39 & $0.46^{*}$ & -0.31 & $-0.54 *$ & 0.09 & $0.59 *$ & 0.29 \\
\hline OTAXA & -0.20 & -0.14 & -0.21 & $-0.60^{*}$ & -0.33 & -0.33 & -0.29 & 0.34 & 0.0 & -0.04 & 0.03 & -0.24 \\
\hline MTAXA & 0.08 & -0.33 & -0.24 & -0.23 & -0.20 & -0.02 & 0.07 & -0.12 & -0.34 & 0.03 & $0.46^{*}$ & -0.12 \\
\hline OLBI & 0.06 & $0.45^{*}$ & 0.30 & $0.42^{*}$ & 0.16 & 0.12 & 0.16 & -0.12 & 0.16 & 0.0 & -0.31 & 0.33 \\
\hline MGBI & 0.17 & 0.22 & 0.0 & 0.05 & 0.29 & 0.29 & 0.25 & 0.02 & 0.22 & -0.08 & -0.23 & 0.24 \\
\hline MGOLRAT & -0.17 & -0.12 & -0.02 & 0.16 & -0.19 & 0.03 & 0.08 & -0.07 & -0.09 & 0.0 & 0.19 & 0.0 \\
\hline MGDFRM & -0.25 & -0.06 & 0.14 & -0.15 & -0.19 & 0.09 & 0.14 & 0.0 & -0.14 & 0.05 & 0.25 & -0.09 \\
\hline MGRICH & 0.08 & -0.33 & -0.24 & -0.23 & -0.19 & -0.02 & 0.07 & -0.12 & -0.35 & 0.03 & $0.46^{*}$ & -0.12 \\
\hline TXRICH & -0.08 & $-0.46^{*}$ & $-0.41^{*}$ & $-0.54^{*}$ & $-0.41^{*}$ & -0.26 & -0.16 & 0.16 & -0.09 & 0.23 & 0.23 & 0.27 \\
\hline
\end{tabular}

a Significant correlations are designated with an asterisk $(* ; \mathrm{p} \leq 0.05)$

collected and comprises $77 \%$ of the overall community abundance (Table 1). The Bivalvia community was made up almost entirely of Musculium transversum.

The Ephemeroptera (mayflies) were present in 16 of 24 samples. Ephemeroptera abundance ranged from absent in eight samples to $3,278 / \mathrm{m}^{2}$ in sample $19 \mathrm{C}$ (Table 1). Ephemeroptera abundance was greater than or equal to $500 / \mathrm{m}^{2}$ in six of 24 samples, but were entirely absent in eight of 24 samples. The Ephemeroptera community was comprised of two fanilies, two genera, and three species. The majority of the insect community (chironomidae excluded) was comprised of Hexagenia sp.

The estimated abundance values of benthic invertebrates collected in this study are consistent with the estimated abundance values of invertebrates collected in previous studies of the UMR (Eckblad et al. 1977; Butts and Sparks 1982; Neuswanger et al. 1982; Eckblad 1986; Jahn and Anderson 1986; Hornbach et al. 1989). Although there is some variation among studies, estimated abundance values were within the same numeric range regardless of the study. In 1991, the Environmental Management Program, Long Term Resource Monitoring Program (LTRMP) issued an observation bulletin (Eckblad 1991) that reported on the observed decline in abundance of macroinvertebrate communities (primarily the fingernail clams) in the UMR. Data from our study do not support the trends reported in the LTRMP report. Benthos abundances were above the low-level warnings issued in the LTRMP report. Differences in abundances may be due to natural spatial or temporal variation in the invertebrate communities, difference in methods of sampling, or conditions in the river and sediments have changed between the time when the LTRMP report was issued and when we conducted our study.

\section{Deformities in Chironomids}

The frequency of mouthpart deformities in the midge community ranged from a low of zero in samples from 11 stations to a maximum of $13 \%$ in sample 20C (Figure 3). Deformities were present in 13 out of 24 samples in the UMR, although only four of 24 samples had deformities that could be considered ahove the identified background levels of 3-4\% (Dickman et al. 1992).

Different genera of midge exhibit different levels of susceptibility or tolerance to contaminants (Hamilton and Saether 1971; Hare and Carter 1976; Wiederholm 1984; Warwick 1985, 1988). Some genera, such as Pagastia spp., Prodiamesa spp., and Stempellina spp., are quite intolerant and are eliminated from locations with relatively low levels of contaminants, while other genera such as Procladius spp., Chironomus spp., and Cryptochironomus spp. are more tolerant and may persist in contaminated locations (Warwick 1985; Bode 1988). An association between increased contamination and the presence of midge deformities has been observed by several investigators (Hamilton and Saether 1971; Tennessen and Gottfried 1983; Cushman 1984; Wiederholm 1984; Warwick 1985; Diggins and Stewart 1993). Deformities reported in these studies include thickening of the exoskeleton, enlargement and darkening of the head capsule, asymmetry in mouthparts, missing or fused lateral teeth, and antennal deformities. None of the specimens examined in the present study exhibited antennal deformities. Deformities observed in this study occurred only in Procladius spp. and Chironomus spp.

The occurrence of midge deformities is reportedly less than $1 \%$ in nonimpacted or preindustrialization communities (Wiederholm 1984; Warwick et al. 1987). Background levels have been estimated at 3\% to $4 \%$ (Dickman et al. 1992), and investigators have suggested that frequency of deformities in the range of $5-25 \%$ or greater are generally associated with modcrate to severe contamination (Wiederholm 1984; Warwick et al. 1987). Based on these criteria, deformities in midge from the UMR indicate that sediments from only four samples would be classified as "moderately contaminated" (Figure 3). Deformities of midges in samples from the UMR were considerably lower than those from contaminated sediments in studies from either the Milltown Reservoir/Clark Fork River (Canfield $e t$ al. 1994) or the Great Lakes (Canfield et al. 1996). These data 


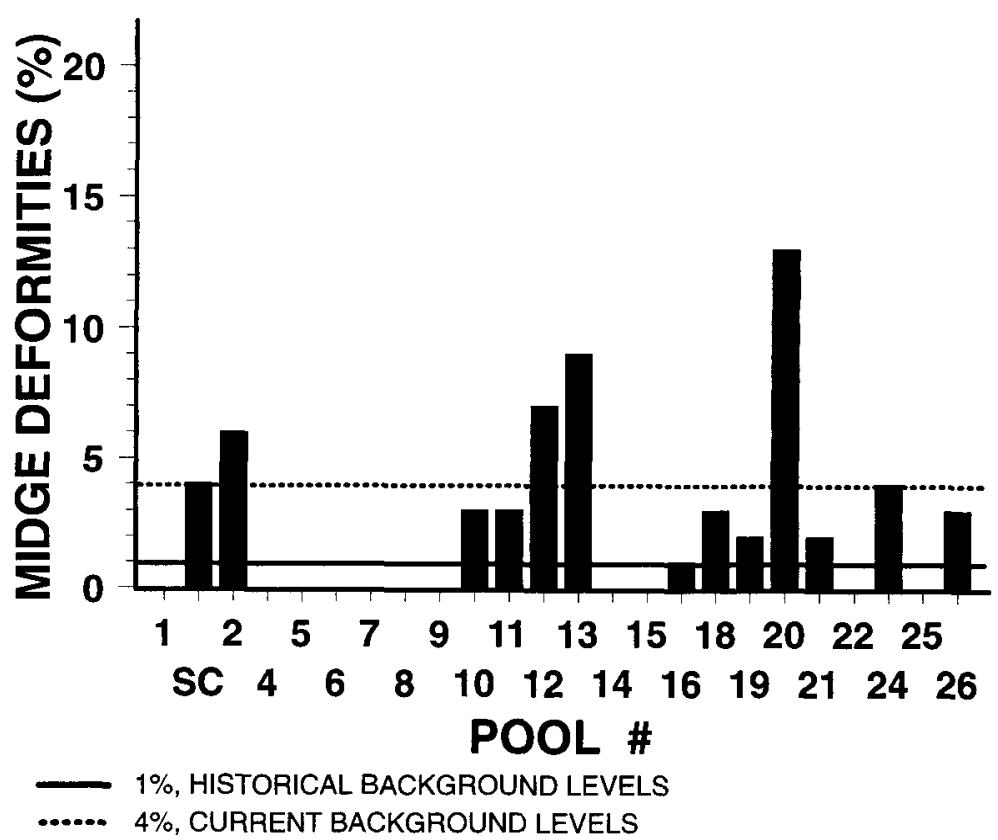

Fig. 3. Comparison of chironomid deformities (\%) for samples from the UMR samples. Solid line (-) represents the $1 \%$ historical background level of deformities (based on analysis of core samples of preindustrialization sediments) and the dashed line (- . . - - ) represents the $4 \%$ current background levels from modern day studies of uncontaminated sediments indicate that overall the sediments in the UMR are uncontaminated relative to other locations with documented occurrences of deformities in midges.

\section{Correlation Data}

Spearman rank correlations were used to compare associations of physical and chemical measures to benthic responses because of non-normal distribution of data (Snedecor and Cochran 1982). Few significant correlations were detected between benthic parameters and either contaminants or abiotic factors evaluated (Table 2). Significant negative correlations were observed between total Ephemeroptera abundance $(\mathrm{r}=-0.43)$ and total abundance $(\mathrm{r}=-0.54)$ with percent sand. Conversely, significant positive correlations were observed between clay and total numbers $(r=0.59)$, bivalve abundance $(r=0.49)$, chironomid abundance $(r=0.48)$, Ephemeroptera abundance $(r=0.47)$, number of chironomid genera $(r=0.46)$, and number of chironomid taxa $(r=0.46)$. Positive correlations with clay and negative correlations with sand imply that hydrological factors such as current velocity may have been determinants of benthic distributions. For example, clay-dominated areas may support greater benthic nymphs due to increased stability of physical habitat and increased deposition of organic matter compared to sandy areas. However, abiotic causality is difficult to infer without additional manipulative studies.

With respect to measures of chemical contamination, significant positive correlations were observed between total abundance (TOTAL) and zinc ( $\mathrm{Zn})$, and between the oligochaete biotic index (OLBI) and both chrysene (CHRYS) and cadmium (Cd). Significant negative correlations were observed between number of oligochaete taxa (OTAXA) with cadmium (C.d) and total taxa richness (TXRICH) with chrysene, benzo(a)pyrene (BAP), cadmium, and nickel (Ni) (Table 2). Although these correlations were significant, they explain no more than $35 \%$ of the total variability. Furthermore, the number of positive and negative correlations varied within a particular chemical. This makes interpretation difficult, but may not be unexpected given that the measured chemicals in almost all the sediments were extremely low compared to sediments in other locations in the United States and the relative weakness of nonparametric correlations as statistical tools.

\section{Sediment Quality Triad}

Spearman rank correlations described above were used to make initial comparisons between measures of the benthic invertebrate community and measures of sediment chemistry or overlying water quality at the sampling stations. While rank correlation analysis can be used to demonstrate association among variables, this ranking of data eliminates proportional relationships among variables by reranking data to simple rank order (e.g., 1, 2, 3). Thus, this ranking can not be used to adequately evaluate dose-response relationships. For these reasons, we evaluated benthic community and laboratory toxicity data using a quadrant classification approach described below (see also Canfield et al. 1996).

Results of toxicity and chemistry evaluations of UMR sediments presented in Kemble et al. (1998) indicate these sediment samples were relatively uncontaminated compared to other locations in the United States (Kemble et al. 1994; Ingersoll et al. 1996). We used the sediment quality triad approach in order to evaluate how benthic communities sampled from the UMR compared to other locations in the United States we previously have evaluated (Canfield et al. 1994, 1996).

Scores for various benthic indices relating benthic alterations to contaminant levels were previously identified using data sets from the Great Lakes (Canfield et al. 1996) and the Clark Fork River in Montana (Canfield et al. 1994). These scores were used to evaluate the scores for samples from the current study. In the present study, benthos samples were not classified as impacted 
Table 3. Summary of quadrant analysis for scores of individual benthic measures and combined benthic metrics for the sum ERM-quotients (SERM-Q: ERM-Q = concentration of a chemical in sediment sample/ERM for that chemical) as a score of chemical contamination. Benthos quadrant score is the score which maximized the number of points in quadrants which would be considered "correctly classified" and minimized the incidence of false-negative error (low chemical concentrations and benthos adversely impacted) and false-positive error (high chemical concentrations and benthos not adversely impacted) as established in Canfield et al. 1996. Error-SERM-Q is the combined false positive and false negative error rate $(\%)$

\begin{tabular}{|c|c|c|c|c|c|c|c|c|}
\hline $\begin{array}{l}\text { Number of } \\
\text { Benthic } \\
\text { Indices } \\
\text { in Score }\end{array}$ & $\begin{array}{l}\text { Benthos } \\
\text { Score }\end{array}$ & $\begin{array}{l}\text { Error- } \\
\text { SERM-Q } \\
(\%)\end{array}$ & $\begin{array}{l}\text { Oligochaete } \\
\text { Biotic } \\
\text { Index }\end{array}$ & $\begin{array}{l}\text { Midge- } \\
\text { Oligochaete } \\
\text { Ratio }\end{array}$ & $\begin{array}{l}\text { Midge } \\
\text { Biotic } \\
\text { Index }\end{array}$ & $\begin{array}{l}\text { Midge } \\
\text { Deformities }\end{array}$ & $\begin{array}{l}\text { Midge } \\
\text { Taxa } \\
\text { Richness }\end{array}$ & $\begin{array}{l}\text { Total } \\
\text { Taxa } \\
\text { Richness }\end{array}$ \\
\hline 1 & 80 & 59 & $X$ & & & & & \\
\hline 1 & 80 & 35 & & $X$ & & & & \\
\hline 1 & 80 & 35 & & & $x$ & & & \\
\hline 1 & 75 & 19 & & & & $X$ & & \\
\hline 1 & 81 & 34 & & & & & $X$ & \\
\hline 1 & 75 & 34 & & & & & & $\mathrm{X}$ \\
\hline 2 & 80 & 28 & & & $X$ & & & $X$ \\
\hline 3 & 81 & 18 & & $x$ & $x$ & & & $\mathrm{X}$ \\
\hline 3 & 81 & 15 & & $X$ & & & $X$ & $X$ \\
\hline 3 & 81 & 24 & & & $X$ & & $X$ & $X$ \\
\hline 3 & 80 & 19 & & $X$ & $X$ & & $X$ & \\
\hline Total & & & 1 & 4 & 5 & 1 & 4 & 5 \\
\hline
\end{tabular}

Table 4. Summary of sediment quality triad data ${ }^{\mathrm{a}}$

\begin{tabular}{|c|c|c|c|c|c|}
\hline Chemistry & Toxicity & Benthos & Pool Number & $\%$ of Samples & Possible Conclusions \\
\hline+ & + & + & None & 0 & Evidence of contaminant-induced degradation \\
\hline - & - & - & All pools except 4,7 , and 26 & 88 & No evidence of contaminant-induced degradation \\
\hline+ & - & - & None & 0 & Contaminants not bivavailable \\
\hline- & + & - & 26 & 4 & $\begin{array}{l}\text { Chemicals not measured or conditions exist with poten- } \\
\text { tial to cause degradation }\end{array}$ \\
\hline- & - & + & 7 & 4 & Benthos response not due to contaminants \\
\hline+ & + & - & None & 0 & Contaminants may be stressing system \\
\hline- & + & + & None & 0 & $\begin{array}{l}\text { Unmeasured chemicals or other conditions causing deg } \\
\text { radation }\end{array}$ \\
\hline+ & - & + & 4 & 4 & $\begin{array}{l}\text { Chemicals not bioavailable or response not due to } \\
\text { chemistry }\end{array}$ \\
\hline
\end{tabular}

${ }^{a}$ A plus ( + ) for chemistry indicates a concentration of contaminants that exceed a SERM-Q score of 39 . A plus ( + ) for laboratory toxicity is based on a Hyalella azteca 28-day growth and survival score of $>30$. A plus $(+)$ for benthos is based on a combined metric of midge-oligochaete ratio, midge taxa richness, and total taxa richness score of $>81$

or nonimpacted a priori, rather, samples were considered to be classified as "incorrect" only if the scores were in the falsepositive or false-negative error quadrants as established in Canfield et al. (1996) (Figure 2).

Four benthic indices (midge biotic index, midge richness, percent midge deformities, and taxa richness) were previously found to provide some degree of discrimination among samples from the Great Lakes with differing degrees of contamination (Canfield et al. 1996). In the present study, midge deformities had the smallest combined false positive and false negative error rate $(19 \%)$ relative to the sum of the ERM quotient score (Table 3). Midge oligochaete ratio, midge biotic index, midge taxa richness, and total taxa richness had a combined false positive and false negative error rate of 34-35\%. A benthos score required to obtain this degree of discrimination was always $\geq 75 \%$.

In addition to assessments using single indices, the combined scores of benthic indices were evaluated, which provided the best classification (smallest combined false positive and false negative error). Quadrant classification using the sum of the
ERM quotient scores of two to three combined benthic indices reduced the false positive and false negative error rate to $19-24 \%$, which is less than all individually scored benthic indices except midge deformities (Table 3 ). The various combinations of four to all six benthic indices were not included in or discussed because the accuracy of classification did not increase with combinations of more than three benthic indices (Table 3). The combinations were restricted so that the benthos score required to minimize false positive and false negative error was no greater than $80-81$. We were unable to identify a combined score of less than 80 that minimized both false positive and false negative error. The combined metric of midge oligochaete ratio, midge taxa richness, and total taxa richness provided the combination that had the lowest false positive and false negative error of $19 \%$ (Table 3 ).

Table 4 summarizes the classification of sediment samples based on eccedences of scores for toxicity, chemistry, or benthos by quadrant analyses as described in Canfield $e t$ al. (1996). Twenty-one of 24 samples ( $88 \%$ ) showed good agreement (i.e., all "minuses") among all three measures of the 
Triad, which indicated that no contaminant induced degradation was observed (Table 4). None of the samples were scored with all pluses (i.e., evidence of contaminant-induced degradation). In onc of the $24(4 \%)$ samples, laboratory toxicity and sediment chemistry measures were in agreement, however the benthic component was not in accordance. Similarly, in one of the samples sediment chemistry and benthos response are in agreement, yet toxicity did not occur. High concordance among laboratory toxicity, chemistry, and benthos is evidence that these sediment samples from the UMR were relatively low in contamination or toxic effects compared to other locations we have previously evaluated (Canfield et al. 1994, 1996).

\section{Conclusions}

Benthic invertebrate abundance and community composition values in sediment samples from the UMR were comparable in numeric magnitude and overall range of variability to values reported from relatively uncontaminated sediments. The percent composition of the benthic invertebrate community also indicates a relatively healthy community compared to more contaminated locations. Oligochaetes and chironomids constituted over $90 \%$ of the benthic invertebrate communities collected in 10 of 24 samples from the UMR, which is expected given the predominance of soft sediments. However, most of the UMR pools had a relatively high diversity of representatives from orders other than the oligochaetes and chironomids, which is different from observations from other highly contaminated areas (Canfield et al. 1994, 1996). Further, benthic community indices were only weakly correlated with sediment contaminants.

The occurrence of midge deformities ranged from 0 to $13 \%$ in the UMR pool samples, which was relatively low compared to those chironomids from more highly contaminated sediments. Sediment quality triad analyses classified a high percentage of the samples $(88 \%)$ to be not impacted. These data indicate that these sediment samples were relatively uncontaminated.

Additional studies are needed to evaluate specific contaminant, biotic, and abiotic factors controlling benthic communities in soft sediments associated with backwater areas of both lotic and lentic environments. Studies designed to evaluate benthic distributions in relation to factors influencing variation on a local micro habitat scale are necessary in order to reduce the variation in the relations between sediment chemistry, habitat, and measures of benthic invertebrate communities. These studies should greatly expand our ability to evaluate environmental quality of ecosystems such as the UMR.

Acknowledgments. The authors would like to thank the following individuals for their input on the project: Doug Hardesty, Chris Henke, John Moody, Shane Ruessler, Julie Soltvedt, Jeff Steevens, Dave Whites, and the Crew of the Acadiana (Craig LeBoeuf and Pat Marmande). We would like to thank James Fairchild, David Mount, and Parley Winger and two anonymous reviewers for constructive criticism and review of this manuscript. We thank Pamela Haverland and Ellen Eherhart for their statistical help in developing the benthic metrics. We also thank Tom Armitage and Betsy Sutherland and the US EPA Office of Water for financial support. Reference to trade names or manufactures does not imply government endorsement of commercial products. This paper has been reviewed in accordance with US EPA policy.

\section{References}

Bailey PA, Rada RG (1984) Distribution and enrichment of trace metals $(\mathrm{Cd}, \mathrm{Cr}, \mathrm{Cu}, \mathrm{Ni}, \mathrm{Pb}, \mathrm{Zn})$ in bottom sediments of Navigational Pools 4 (Lake Pepin), 5, and 9 of the Upper Mississippi River. In: Wiener JG, Anderson RV, McConville DR (eds) Contaminants in the Upper Mississippi River. Butterworth Publishers, Boston, MA, pp 119-138

Bode RW (1988) Quality assurance work plan for biological stream monitoring in New York State. New York State Department of Environmental Conservation

Brinkhurst RO, Chua KE, Kaushik NK (1972) Interspecific interaction and selective feeding of tubificid oligochaetes. Limnol Oceanogr 17:122-133

Brunson EL, Canfield TJ, Dwyer FJ, Ingersoll CG, Kemble NE (1998) Assessing bioaccumulation of contaminants from sediments from the Upper Mississippi River using field-collected oligochaetes and laboratory-exposed Lumbriculus varigatus. Arch Environ Contam Toxicol 35:191-201

Burt AJ, McKee PM, Hart DR, Kauss PB (1991) Effects of pollution in benthic invertebrate communities of the St. Marys River, 1985. Hydrobiologia 219:63-81

Burton GA Jr, Ingersoll CG, Burnett L, Henry M, Hinman M, Klaine S, Landrum P, Ross P (1996) A comparison of sediment toxicity test methods at three Great Lakes Areas of Concern. J Great Lakes Res 22:495-511

Butts TA, Sparks RE (1982) Sediment oxygen demand: fingernail clam relationship in the Mississippi River Keokuk Pool. Trans III Acad Sci 75:29-39

Canfield TJ, Kemble NE, Brumbaugh WG, Dwyer FJ, Ingersoll CG, Fairchild JF (1994) Use of benthic invertebrate community structure and the sediment quality triad to evaluate metalcontaminated sediment in the upper Clark Fork River, Montana. Environ Toxicol Chem 13:1999-2012

Canfield TJ, Dwyer FJ, Fairchild JF, Haverland PS, Ingersoll CI, Kemble NE, Mount DR, La Point TW, Burton GA, Swift MC (1996) Assessing contamination in Great Lakes sediments using benthic invertebrate communities and the sediment quality triad approach. J Great Lakes Res 22:565-583

Chapman PM, Power EA, Burton GA Jr (1992) Integrative assessments in aquatic ecosystems. In Burton Jr GA (ed) Sediment toxicity assessment. Lewis Publishers, Chelsea, MI, pp 313-340

Chutter FM (1972) An emperical biotic index of the quality of water in South African streams and rivers. Water Res 6:19-30

Clements WH, Cherry DS, Van Hassel JH (1992) Assessment of the impact of heavy metals on benthic communities at the Clinch River (Virginia): evaluation of an index of community sensitivity. Can J Fish Aquat Sci 49:1686-1694

Cook DG, Johnson MG (1974) Benthic macroinvertebrates of the St. Lawrence Great Lakes. J Fish Res Bd Can 3:763-782

Cook SEK (1976) Quest for an index of community structure sensitive to water pollution. Environ Poll 11:269-288

Cushman RM (1984) Chironomid deformities as indicators of pollution from a synthetic, coal-derived oil. Freshwater Biol 14:179-182

Davis WS, Lathrop JE (1992) In Sediment classification methods compendium. U.S. Environmental Protection Agency, Watershed Protection Division, Office of Water, EPA 823-R-92-006, chapter 8, pp 8-1-8-26

Dickman M, Brindle I, Benson M (1992) Evidence of teratogens in sediments of the Niagra River watershed as reflected by chironomid (Diptera: Chironomidae) deformities. J Great Lakes Res $18: 467-480$ 
Diggins TP, Stewart KM (1993) Deformities of aquatic larval midges (Chironomidae: Diptera) in the sediments of the Buffalo River, New York. J Great Lakes Res 19:648-659

Eckblad JW (1986) The ecology of pools 11-13 of the Upper Mississippi River: a community profile. US Fish Wildl Serv Biol Rep 85 (7.8), 90 pp

Eckblad JW (1991) LTRMP Observational Bulletin No. 1: Status of macroinvertebrate populations of the Upper Mississippi River. US Fish Wildl Serv Enviro Manage Tech Ctr, 8 pp

Eckblad JW, Peterson NL, Ostlie K (1977) The morphometry, benthos and sedimentation rates of a floodplain lake in Pool 9 of the Upper Mississippi River. Am Midl Nat 97:433-443

Forstner U, Wittmann GTW (1980) Metal pollution in the aquatic environment. Berlin: Springer-Verlag, 197 pp

Hamilton AL, Saether OA (1971) The occurrence of characteristic deformities in the chironomid larvae of several Canadian lakes. Can Int 103:363-368

Hare L, Carter JCH (1976) The distribution of Chironomus (s.s) cucini (salinarius group) larvac (Diptera: Chironomidac) in Parry Sound, Georgian Bay, with particular reference to structural deformities. Can J Zool 54:2129-2134

Hassett JJ, Means JC, Banwart WL, Wood SG (1980) Sorption properties of sediments and energy related pollutants. US Environmental Protection Agency Report, EPA-600/3-80-041, Environmental Research Laboratory, Athens, GA

Hilsenhoff WL (1982) Using a biotic index to evaluate water quality in streams. Technical Bulletin No. 132, Department of Natural Resources, Madison, WI

Hilsenlioff WL (1987) An improved biotic index of organic stream pollution. Great Lakes Entomol 20:31-39

Hornbach DJ, Deneka T, Payne BS, Miller AC (1989) Benthic macroinvertebrate community structure in a backwater lake of pool 2, Upper Mississippi River. J Fresh Ecol 5:131-138

Ingersoll CG, Haverland PS, Brunson EL, Canfield TJ, Dwyer FJ, Henke CE, Kemble NE, Mount DR (1996) Calculation and evaluation of sediment effect concentrations for the amphipod Hyalella azteca and the midge Chironomus riparius. J Great Lakes Res 22:602-623

Jahn LA, Anderson RV (1986) The ecology of pools 19 and 20, Upper Mississippi River: a community profile. US Fish Wildl Serv Biol Rep 85 (7.6), 142 pp

Kemble NE, Besser JM, Brumbaugh WG, Brunson EL, Canfield TJ, Coyle JJ, Dwyer FJ, Fairchild JF, Ingersoll CG, La Point TW, Meadows JC, Monda DP, Poulton BC, Woodward DF, Zajicek JL (1993) Sediment toxicology. In: Effects of metal-contaminated sediment, water, and diet on aquatic organisms. PB93-215952, US Environmental Protection Agency, Helena, MT, pp 2-1-2-100

Kemble NE, Brumbaugh WG, Brunson EI, Dwyer FJ, Ingersoll CG, Monda DP, Woodward DF (1994) Toxicity of metal-contaminated sediments from the upper Clark Fork River, Montana, to aquatic invertebrates and fish in laboratory exposures. Environ Toxicol Chem 13:1985-1997

Kemble NE, Brunson EL, Canfield TJ, Dwyer FJ, Ingersoll CG (1998) Assessing sediment toxicity from navigational pools of the Upper Mississippi River using a 28-day Hyalella azteca test. Arch Environ Contam Toxicol 35:181-190

Kennedy CR (1965) The distribution and habitat of Limnodrilus claparede and its adaptive significance. Oikos 16:26-28

Kreis RG (1988) Integrated study of exposure and biological effects of in-place sediment pollutants in the Detroit River, Michigan: an upper Great Lakes connecting channel. Final Report. US Environmental Protection Agency, Office of Research and Development, ERL-Duluth, MN, and LLRS-Grosse Ile, MI, $153 \mathrm{pp}$

Lenat DR (1993) A biotic index for the southeastern United States derivation and list of tolerance values, with criteria for assigning water-quality ratings. J North Am Benth Soc 12:279-290

Long ER, MacDonald DD, Smith SL, Calder FD (1995) Incidenc of adverse biological effects within ranges of chemical concentra- tions in marine and estuarine sediments. Environ Manage 19: $81-97$

Medine AJ, McCutcheon SC (1989) Fate and transport of sedimentassociated contaminants. In Saxena $\mathbf{J}$ (ed) Hazard assessment of chemicals, vol. 6. Hemisphere Publishing Co., New York, NY, pp 225-291

Merritt RW, Cummins KW (eds) (1984) An introduction to the aquatic insects of North America. Kendall/Hunt Publishing Co., Dubuque, Iowa, $722 \mathrm{pp}$

Milbrink G, Wiederholm T (1973) Sampling efficiency of four types of mud bottom samplers. Oikos 24:479-482

Moody JA, Meade RH (1995) Hydrologic and sedimentologic data collected during three cruises on the Mississippi River and some of its tributaries from Minneapolis, Minnesota, to New Orleans, Louisiana, July 1991-May 1992. US Geological Survey Open File Report 94-474

Moody JA (ed) (1996) Hydrologic, sedimentologic, and chemical data describing surficial bed sediments in the navigation pllos of the Upper Mississippi River after the flood of 1993. U.S. Geological Survey Open File Report 96-580

Neuswanger DJ, Taylor WW, Reynolds JB (1982) Comparison of macroinvertebrate herpobenthos and haptobenthos in side channel and slough in the Upper Mississippi River. Freshwat Invertebr Biol $1: 13-24$

Nielson DN, Rada RG, Smart MM (1984) Sediments of the Upper Mississippi River: their sources, distribution, and characteristics. In Wiener JG, Anderson RV, McConville DR (eds) Contaminants in the Upper Mississippi River. Butterworth Publishers, Boston, MA, pp 67-98

Oschwald W (1972) Sediment-water interactions. J Environ Qual $1: 360-366$

Pennak RW (1989) Fresh-water invertebrates of the United States: protozoa to Mollusca, 3d ed. John Wiley, New York, NY, $628 \mathrm{pp}$

Pratt JM, Coler RA (1976) A procedure for the routine biological evaluation of urban runoff in small rivers. Water Res 10:10191025

Rada RG, Wiener JG, Bailey PA, Powell DE (1990) Recent influxes of metals into Lake Pepin, a natural lake on the Upper Mississippi River. Arch Environ Contam Toxicol 19:712-716

Rosenberg DM, Wiens AP (1976) Community and species responses of Chironomidae (Diptera) to contamination of fresh waters by crude oil and petroleum products, with special reference to the Trail River, Northwest Territories. J Fish Res Board Can 33:1955-1963

Saether OA (1970) A survey of the bottom fauna in lakes of the Okanagan Valley, British Columbia. Fish Res Bd Can Tech Rep 342:1-27

Shimp N, Schleicher J, Ruch R, Heck D, Leland H (1971) Trace element and organic carbon accumulation in the most recent sediments of southern Lake Michigan. Environmental Geology Notes, Illinois State Geological Survey, 41, 25 pp

Sorensen DL, McCarthy MM, Middlebrooks EJ, Porcella DB (1977) Suspended and dissolved solids effects on freshwater biota: $a$ review. EPA-600/3-77-042, National Technical Information Service, Springfield, VA

Snedecor GW, Cochran WG (1982) Statistical methods, 7th ed. The Iowa State University Press, Ames, IA

SAS Institute (1994) SAS user's guide: statistics, version 6.10. SAS Institute Inc., Cary, NC, 1029 pp

Tennessen KJ, Gottfried PK (1983) Variation in structure of ligula of Tanypodinae larvae (Diptera: Chironomidae). Ent News 94:109_ 116

Thorp JH, Covich AP (eds) (1991) Ecology and classification of North American freshwater invertebrates. Academic Press Inc., San Diego, CA, $911 \mathrm{pp}$

US Environmental Protection Agency (1993) Assessment and remediation of contaminated sediments (ARCS) program. Biological and chemical assessment of contaminated Great Lakes sediment. EPA 905-R93-006, Chicago, IL 
US Environmental Protection Agency (1994) Assessment and remediation of contaminated sediments (ARCS) program. Assessment guidance document. EPA 905-B94-002, Chicago, IL

US Environmental Protection Agency (1997) An assessment of sediments from the Upper Mississippi River final report June 1997. EPA 82.3-R-97-005, Washington, DC

Van der Leeden F, Troise FL, Todd DK (1990) The water encyclopedia, $2 \mathrm{~d}$ ed. Lewis Publishers, Inc., Chelsea, MI, $808 \mathrm{pp}$

Warwick WF (1985) Morphological abnormalities in Chironomidae (Diptera) larvae as measures of toxic stress in freshwater ecosystems: indexing antennal deformities in Chironomus Meigan. Can J Fish Aquat Sci 42:1881-1941

Warwick WF (1988) Morphological deformities in Chironomidae (Diptera) larvae as biological indicators of toxic stress. In: Evans MS (ed) Toxic contaminants and ecosystem health: a Great Lakes focus. John Wiley and Sons, New York. NY, pp 281-320

Warwick WF (1989) Morphological deformities in larvae of Procladius
Skuse (Diptera: Chironomidae) and their biomonitoring potential. Can J Fish Aquat Sci 46:1255-1270

Warwick WF, Fitchko J, McKee PM, Hart DR, Burt AJ (1987) The incidence of deformities in Chironomus sp. from Port Hope Harbour, Lake Ontario. J Great Lakes Res 13:88-92

Waterhouse JC, Farrell MP (1985) Identifying pollution related changes in chironomid communities as a function of taxonomic rank. Can J Fish Aquat Sci 42:406-413

Wiebe $\Lambda H$ (1927) Biological survey of the Upper Mississippi River, with special reference to pollution. Bull Bur Fish 43:137-167

Wiederholm T (ed) (1983) Chironomidae of the Holoartic region: keys and diagnoses, Part 1. Larvae. Entomologia Scandinavica, Supplement no. 19

Wiedcrholm T (1984) Incidence of deformed chironomid larvae (Diptera: Chironomidae) in Swedish lakes. Hydrobiologia 109:243-249

Wiener JG, Jackson GA, May TW, Cole BP (1984) Contaminants in the Upper Mississippi River. Butterworth Publishers, Boston, MA, $368 \mathrm{pp}$ 